\title{
The Impact of Business Incubator Facilities on Investment Promotion in Jordan: A Case of King Hussein Business Park
}

\author{
Ibrahim Alshamaileh $^{1} \&$ Fouad Sheikh Salem ${ }^{1}$ \\ ${ }^{1}$ Faculty of Business, Amman Arab University, Amman, Jordan \\ Correspondence: Ibrahim Adnan Jamil Alshamaileh, Faculty of Business, Amman Arab University, Amman, \\ Jordan.
}

\author{
Received: July 10, 2018 Accepted: August 3, 2018 Online Published: August 21, 2018 \\ doi:10.5539/jms.v8n3p55 URL: https://doi.org/10.5539/jms.v8n3p55
}

\begin{abstract}
This study aims to measure the impact of facilities provided by King Hussein Business Park on investment promotion. King Hussein Business Park has reached $100 \%$ occupancy rate, with a crucial plan for expansion to over 1.4 million $\mathrm{m}^{2}$ of land. The problem of the study lies on how King Hussein Business Park will attract additional investments to occupy the spaces targeted for expansion. Results of the study reveal a significant positive impact of the facilities on investment promotion. The robust infrastructure, complementary services, and investment law benefits influence the creation of attractive business environment for investments. These findings show that countries with scarce resources face many challenges in promoting investment either locally or internationally, and they must improve their business climate for investment promotion. Governments also have the means to make conducting the businesses and projects easier for people.
\end{abstract}

Keywords: facilities, investment promotion, infrastructure, investment law benefits, governmental reforms

\section{Introduction}

Competition in how to attract investors for achieving economic growth has been increasing at local and global levels, particularly for developing countries (Rondinelli \& Burpitt, 2000). According to global trends, increasing the flow of foreign direct investment (FDI) is of interest because it is one of the three main foundations of globalization. The flow of FDI in developing countries has increased as a result of the implementation of successful economic strategies and improvements of the investment climate (United Nations Publication, 2004, p. 5). This study is very important because it is seeking to explore the factors and dimensions that contribute to the investment promotion and providing results that contribute greatly to increase the national economy growth and to achieve the economic stability. Problem statement theoretically is that the topics of promoting investment did not have their shares of deep study and analysis in the Middle East compared to other countries. On the practical side, the interest in investment promotion either locally or internationally has increased because it is the key to economic growth and the best way to achieve the sustainable development (Reich, 2006). Investment promotion in many countries faces many obstacles brought about by crises, governmental policies, investment law, and required facilities. Local and foreign direct investments also have problems related to investment tax credit, personal property, tax exemption, tax incentives, and private equity in Washington (Koo, 2016). Previous studies conclude that to guarantee investment promotion, the most important step is introducing investment law benefits, such as tax reductions, tax exemptions, and tax incentives. Doing so can certainly promote investment either locally or internationally. In the past few decades, a large number of developing countries have tried to attract FDI through various policy reforms, such as introducing streamlined foreign ownership procedures, improving the procedures in investment projects for foreign organizations, and focusing on the methods to develop the infrastructure. The barriers in developing countries are greater than in developed countries, which prevent investment promotion either locally or internationally. Moreover, the policy reforms, such as removing the ownership restrictions, contribute in increasing the flow of FDI, which can, in turn, create a supportive environment for local investments (Tanaka \& Arita, 2016).

Nowadays, developing economies become the destination of FDI inflows. India focuses on further improving its infrastructure facilities to attract foreign investment in the future (Kaur, Khatua, \& Yadav, 2016). The quality of infrastructure has a considerable influence on the inflows of FDI. The infrastructure environment in India has rapidly developed in the past two decades, becoming one of the countries with largest road networks in the world. 
The multi-integration of road networks, railways, and ports allows easy access to the remotest side of the country. India has also focused on how to develop its infrastructure in all fields to further attract FDI.

Moreover, FDI can play an important role in the economic growth of least developing countries like Bangladesh (Sharmen, Zahurul, \& Khaled, 2015). The Bangladesh government has reformed a few facilities and gave incentives for entrepreneurs to attract more FDI. Therefore, efforts were exerted to find which determinants influence the attraction of FDI to develop Bangladesh Industries. FDI plays an effective role in fulfilling local demand and developing local investments (Chowdhwry \& Shao, 2016). Bangladesh economy is rapidly improving. The gross domestic product growth has reached 6.5 billion due to labor cost and productivity, trade agreements facilities, investment benefits, taxes, duty free access, offshore banking unit, and regulatory policies.

Jordan is keen to promote domestic and foreign investments to enhance economic growth (Arabyat, 2016). The importance to promote investment in Jordan is evident from the increased attention from the government (Magableh \& Ajlouni, 2016). Jordan's government focuses on the factors that influence investment promotion. The government also concentrates on governmental reforms, capital expenditures, and improvement of the private sector to boost the flow of investments in Jordan.

The Investment Law enhances Jordan's competitive position, ranking it 89th worldwide as of 2015, this ranking was retrieved from https://en.wikipedia.org/wiki/Economy_of_Jordan. The Investment Law also creates a legislative and regulatory environment aimed at facilitating and serving international and Jordanian investors alike.

\section{Literature Review}

The topic of investment promotion either locally or internationally is the most relevant part of economic and social growth, as this topic plays an important role in achieving the economic stability. Investment promotion provides competitive advantage and ease in doing business and empowers the private sector's role in development and regulations (Dorożyński, Świerkocki, \& Urbaniak, 2014).

Investment promotion helps to boost local and FDI and enhance their contribution to the national economic development and growth. How to utilize resources most effectively and efficiently and organize investment promotion activities within the government should be calculated to succeed in investment promotion. Thus, the main goal of economic development through improvements in the investment climate remains at the front of policymaking. Investment promotion leads to many results, such as accelerating growth and development, diversifying the economy, and generating new employment opportunities (Rondinelli \& Burpitt, 2000). Investment in human resources, facilitation of investment procedures, flexibility of investment laws and regulations, and improvement of infrastructure can enhance FDI and increase the volume of inflows and returns from foreign investments (Issani \& Sallali, 2016).

Governmental incentives and other competitive factors have an impact on attracting and retaining international investment. During the 1990s, the globalization of markets and economic competition encouraged state governments to offer both tax and exemptions incentives to attract investments not only from other states but also from other countries (Rondinelli \& Burpitt, 2000).

Tembe and $\mathrm{Xu}$ (2012) determined a significant difference between China and Mozambique in terms of investment promotion because of their geographical and distinct locations, infrastructure conditions (poor or developed), corruption, taxation, and governmental policies. The motivational factors, such as political stability, raw material availability, economic stability, social stability, strategic location, investment benefits, and tax reduction, create a supportive environment for investments and help attract and retain FDI (Frimpong \& Nubuor, 2013).

Stanković and Radenković (2017) recommended focusing on efficiency of cities and municipalities to have a favorable business environment with many criteria to attract investments in Serbia. The criteria include governmental policies and awareness, the quality of services, business climate and environment, regional development, unemployment rate, and infrastructure and transparency level.

Unsuitable infrastructure may hinder investment (Gani \& Mainul, 2012), and such is the issue for Bangladesh. The nature of infrastructure and other problems affect the investment decisions of entrepreneurs in the country. Other factors also affect investment, including infrastructure, tax policy, governance, finance policy, labor and employment, and policy and enterprise. Many infrastructural problems exist, and investors have given several suggestions to prevent an adverse effect on local investment promotion.

The Indonesian government introduced improved tax facilities for investment in 2016, which aims to foster economic growth and accelerate development in certain regions of the country as well as attract local and foreign 
capital investments in certain industries (Karyadi \& Puspita, 2016). The improved tax facilities include tax incentives, which are offered to the taxpayers and income tax. The tax incentives exert a positive effect on promoting local and FDI.

The limited economic resources of Ukraine create problems in search for additional sources. One of these sources is local and foreign investment. The investment environment is affected by legal, political, economic, and social factors. The importance of each factor in a particular country is different because it counts on the level of economic development and trends. Stable investment climate can attract investment either locally or internationally. Despite the limited economic resources in Ukraine, other factors attract investors in Ukraine, such as available information about its potential resources, good infrastructure, many kinds of raw material, geographical location, and service resources, like land and water resources (Serhieieva, 2015). Ukrainian economy has always been appealing to local and foreign companies. By expanding the country's activities, the investment in the Ukrainian market leads to the high profits apart from the few risks.

Thus, the researcher suggested the following conceptual research framework based on previous studies.

\section{Facilities}

investment promotion

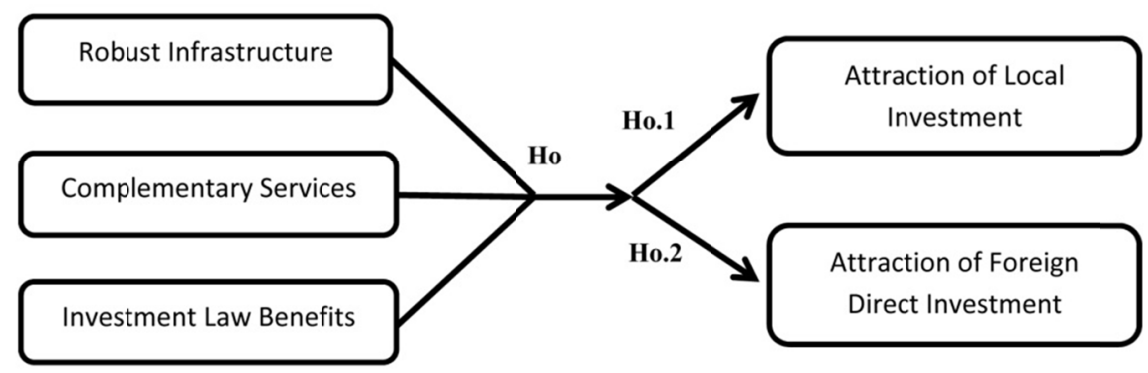

Figure 1. Conceptual Research Framework

\section{Hypothesis of the Study}

This study provides the following hypotheses based on the preceding conceptual framework.

Ho: There is no statistically significant impact for the King Hussein Business Park facilities on investment promotion.

Ho.1: There is no statistically significant impact for the King Hussein Business Park facilities on the attraction of local investment.

Ho.2: There is no statistically significant impact for the King Hussein Business Park facilities on the attraction of foreign direct investment.

\section{Methodology}

The researcher used descriptive analytical method to analyze and classify the data. The researcher recorded the views available for study then presented and described these through tables and graphs. This method was utilized to obtain adequate measurements (Rondinelli \& Burpitt, 2000; Issani \& Sallali, 2016).

The researcher developed a questionnaire covering all components of the dependent and independent study variables, which were formulated and distributed to the members of the sample unit to increase the reliability of the data to be collected. Nine items were used to measure the impact of robust infrastructure on investment promotion (Tembe \& Xu, 2012), eight items were used to assess the impact of complementary services (Stanković \& Radenković, 2017), and six items were utilized to measure the impact of investment law benefits on investment promotion (Frimpong \& Nubuor, 2013). The researcher relied on measuring the variables of the study depending on the standards contained in previous and reliable studies. The researcher used a five-point Likert scale to achieve the objectives of the study. This technique is used to obtain adequate measurements (Hair, Black, Babin, \& Anderson, 2010).

The study sample included all the companies of King Hussein Business Park, where a questionnaire was distributed to collect the information and relevant data. The study population consisted of 150 active companies as of January 30, 2018, distributed within one location. The researcher took into consideration the seven business sectors (information and communications technology, media, healthcare, education, international organizations, none governmental organizations and start-ups). The researcher selected the stratified sample and distributed 300 questionnaires, which were all returned after being filled. 
The researcher tested the face validity to know the questions associated with each other and ensure the consistency of the answers of the sample members. It was presented to a group of experienced professionals and arbitrators consisted of many professors to judge its validity as a tool to collect data.

Regarding to the reliability of the tool, the Cronbach's alpha coefficient was adopted for internal consistency to ensure that the questionnaire is reliable tool to collect the necessary data. The results of Cronbach's alpha coefficient for all study variables are higher than (70\%): robust infrastructure, 0.790 ; complementary services, 0.797; investment law benefits, 0.877; attraction of local investment, 0.744; and, attraction of FDI, 0.792. These results are acceptable based on (Hair, Anderson, Tatham and Black, 2010), and they are mentioned on page 311 in the book Research Methods for Business-Uma Sekaran. The items in the questionnaire for each of the independent and dependent variables, as well as each dimension, all have internal consistency, and these results are reliable.

\section{Profile of Respondents}

A total of 300 managers completed the questionnaire. Most of the respondents in the study population were females as the proportion of females was $51.3 \%$, and that of males was $48.7 \%$. The managers were from all age groups. Managers between 30 and 35 years old represented the highest percentage (28.6\%). Managers between 25 and 30 years old were ranked second $(28.0 \%)$. The lowest category was the managers between 20 and 25 years old (6.0\%). Most managers had sufficient experience and were qualified for their position. According to career level, the highest category of respondents was operations officers (37.0\%), followed by general managers (32.7\%). The lowest category was operations managers $(30.3 \%)$. The questionnaire was distributed more to operations officers. According to academic qualification, the highest category of respondents was bachelor's (48.0\%), followed by master's degree (32.3\%), diploma degree (15.0\%), and $\mathrm{PhD}(4.3 \%)$. The lowest category was high school diploma (0.3\%). From the presented data, most of the respondents were educated, qualified, and skilled. According to practical experience, most of respondents had practical experience from 5 to 10 years (42.0\%). The number of respondents with experience less than 5 years was $65(21.7 \%)$. The lowest category with regard to experience was the managers with more 15 years (16.3\%). Most participants had good practical experience, indicating that the questionnaire data was filled out by managers with high experience and knowledge. According to length of their projects, most projects were from 1 to 3 years old (30.3\%), followed by projects from 3 to 5 years old (28.3\%), and projects from 5 to 8 years old (23.3\%). Projects that lasted more than 8 years old accounted for $18.0 \%$.

\section{Data Analysis}

The researcher estimated the arithmetic mean and standard deviation for all questions which used to measure the dimensions of independent and dependent variables.

Table 1. Independent variable

\begin{tabular}{llllll}
\hline Variable & N & Minimum & Maximum & Mean & Std. Deviation \\
\hline Average IV "Facilities" & 300 & 3.04 & 4.96 & 4.2480 & .32061 \\
IV 1 "Robust infrastructure" & 300 & 3.00 & 5.00 & 4.3474 & .36998 \\
IV 2 "Complementary services " & 300 & 2.88 & 5.00 & 4.4163 & .43364 \\
IV 3 "Investment law benefits & 300 & 2.50 & 5.00 & 3.8744 & .58118 \\
\hline
\end{tabular}

Table 1 indicates that the arithmetic mean of average facilities is 4.2480 with a standard deviation (SD) of 0.32061 . Complementary services were ranked first with arithmetic mean of 4.4163 and SD of 0.43364 . The second was robust infrastructure with an arithmetic mean of 4.3474 and SD of 0.36998 . Investment law benefits were ranked the lowest with arithmetic mean of 3.8744 and SD of 0.58118 .

Table 2. Dependent variable

\begin{tabular}{|c|c|c|c|c|c|}
\hline Variable & $\mathbf{N}$ & Minimum & Maximum & Mean & Std. Deviation \\
\hline Average DV "Promotion of Investment" & 300 & 3.04 & 4.88 & 4.1291 & .31832 \\
\hline DV 1 "Attracting local investment" & 300 & 2.29 & 5.00 & 4.0790 & .42208 \\
\hline DV 2 "Attracting foreign direct investment" & 300 & 2.89 & 5.00 & 4.1544 & .42416 \\
\hline
\end{tabular}


Table 2 shows that the arithmetic mean of average investment promotion is 4.1291 with a standard deviation of 0.31832. The attraction of FDI was ranked first with an arithmetic mean of 4.1544 and standard deviation of 0.42416 , followed by attraction of local investment (arithmetic mean $=4.0790 ; \mathrm{SD}=0.42208$ ).

In the variables normally distributed, moderation was observed in the responses and no dispersion. The plot of regression standardized residual against the expected value indicated that the assumption of linearity was not violated because no relationship exists between the expected and residual values. The result of the DurbinWatson test was 1.978, which approximately equaled 2, that is, between 1.5 and 2.5 (Hair, Anderson, Tatham, \& Black, 1995). No autocorrelation problem exists, so the independence of errors was not violated. The multicollinearity test indicated a high correlation between two or more variables. The VIF value was less than 10 , and the tolerance value was between (0) and (1), implying no collinearity within the independent variables.

$$
\mathrm{VIF}=[(1 / \text { Tolerance })] \quad \text { or } \quad=[(1 /(1-\mathrm{R} \text { square })]
$$

The relationship between independent and dependent variables was mostly moderate because the R-value equals 0.498, which indicates the degree of the relationship between the average facilities and average investment promotion. The R Square equals 0.248 , which means that the independent variables are responsible for $24.8 \%$ of the variation in the dependent variable and $75.2 \%$ are related to other variables. The adjusted $\mathrm{R}$ Square value equals 0.245 , which is the R Square adjusted based on the number of predictors in the model.

The researcher conducted several hierarchical regression models to test the impact of facilities on investment promotion and predict the value of the dependent variable.

Table 3. Coefficients ${ }^{\mathrm{a}}$ - the main hypothesis

\begin{tabular}{|c|c|c|c|c|c|c|c|c|}
\hline \multirow{2}{*}{\multicolumn{2}{|c|}{ Model }} & \multicolumn{2}{|c|}{ Unstandardized Coefficients } & \multirow{2}{*}{$\begin{array}{l}\text { Standardized } \\
\text { Coefficients } \\
\text { Beta }\end{array}$} & \multirow[t]{2}{*}{$\mathbf{T}$} & \multirow[t]{2}{*}{ Sig. } & \multicolumn{2}{|c|}{ Collinearity Statistics } \\
\hline & & $\mathrm{B}$ & Std. Error & & & & Tolerance & VIF \\
\hline \multirow[t]{2}{*}{1} & (Constant) & 1.005 & .089 & & 11.312 & .000 & & \\
\hline & Average IVs & .494 & .050 & .498 & 9.908 & .000 & 1.000 & 1.000 \\
\hline
\end{tabular}

Table 3 demonstrates the power of impact of average facilities on average investment promotion $($ Beta $=0.498)$. The calculated T-value determines whether the sample mean is statistically different from a population mean (T-test $=9.908)$, and the significance level was less than (0.05). Accordingly, the null hypothesis H0 was rejected and alternative hypothesis H1 was accepted. H1 states a statistically significant impact of King Hussein Business Park facilities on investment promotion.

Table 4. Coefficients ${ }^{\mathrm{a}}$ - the first sub hypothesis

\begin{tabular}{|c|c|c|c|c|c|c|c|c|}
\hline \multirow[t]{2}{*}{ Model } & & \multicolumn{2}{|c|}{ Unstandardized Coefficients } & \multirow{2}{*}{$\begin{array}{l}\text { Standardized } \\
\text { Coefficients } \\
\text { Beta }\end{array}$} & \multirow[t]{2}{*}{$\mathbf{T}$} & \multirow[t]{2}{*}{ Sig. } & \multicolumn{2}{|c|}{ Collinearity Statistics } \\
\hline & & $\mathrm{B}$ & Std. Error & & & & Tolerance & VIF \\
\hline \multirow{2}{*}{1} & (Constant) & .967 & .124 & & 7.822 & .000 & & \\
\hline & Average IVs & .544 & .069 & .413 & 7.838 & .000 & 1.000 & 1.000 \\
\hline
\end{tabular}

a. Dependent Variable: Attracting Local Investment

Table 4 indicates a power of impact of independent variables on attracting local investment $($ Beta $=0.413)$. The calculated T-value was 7.838, and the significance level was less than 0.05. Accordingly, H0.1 was rejected. H1.1 was accepted, which states a statistically significant impact of the King Hussein Business Park facilities on the attraction of local investment. 
Table 5. Coefficients $\mathrm{a}$ - the second sub hypothesis

\begin{tabular}{|c|c|c|c|c|c|c|c|c|}
\hline \multirow[t]{2}{*}{ Model } & & \multicolumn{2}{|c|}{ Unstandardized Coefficients } & \multirow{2}{*}{$\begin{array}{l}\text { Standardized } \\
\text { Coefficients } \\
\text { Beta }\end{array}$} & \multirow[t]{2}{*}{$\mathbf{T}$} & \multirow[t]{2}{*}{ Sig. } & \multicolumn{2}{|c|}{ Collinearity Statistics } \\
\hline & & B & Std. Error & & & & Tolerance & VIF \\
\hline \multirow[b]{2}{*}{1} & (Constant) & .812 & .122 & & 6.643 & .000 & & \\
\hline & Average IV & .590 & .069 & .446 & 8.604 & .000 & 1.000 & 1.000 \\
\hline
\end{tabular}

Table 5 shows the power of impact of independent variables on attracting FDI $($ Beta $=0.446)$. The calculated T-value was 8.604, and the significance level was less than 0.05 . Accordingly, H0.2 was rejected, and H1.2 was accepted. H1.2 states a statistically significant impact of the King Hussein Business Park facilities on the attraction of FDI.

Table 6. Multiple regression

\begin{tabular}{|c|c|c|c|c|c|c|c|c|}
\hline \multirow[t]{2}{*}{$\begin{array}{l}\text { Coefficients }^{\mathrm{a}} \\
\text { Model }\end{array}$} & & \multicolumn{2}{|c|}{$\begin{array}{l}\text { Unstandardized } \\
\text { Coefficients }\end{array}$} & \multirow{2}{*}{$\begin{array}{l}\text { Standardized } \\
\text { Coefficients } \\
\text { Beta }\end{array}$} & \multirow[t]{2}{*}{$\mathbf{T}$} & \multirow[t]{2}{*}{ Sig. } & \multicolumn{2}{|c|}{ Collinearity Statistics } \\
\hline & & $\mathrm{B}$ & Std. Error & & & & Tolerance & VIF \\
\hline & (Constant) & 2.082 & .219 & & 9.513 & .000 & & \\
\hline & IV1: Robust infrastructure & .095 & .046 & .111 & 2.069 & .039 & .863 & 1.158 \\
\hline & IV2: Complementary services & .266 & .040 & .363 & 6.727 & .000 & .851 & 1.176 \\
\hline & IV3: Investment law benefits & .118 & .028 & .215 & 4.141 & .000 & .917 & 1.091 \\
\hline
\end{tabular}

Table 6 demonstrates the power of impact of facilities on average investment promotion because of the power of impact of IV1 on DV (Beta $=0.111)$, that of IV2 on DV (Beta $=0.363)$, and that of IV3 on DV (Beta $=0.215)$. The results indicate a positive direct impact of the IVs on average DV. The calculated T-values were as follows: T-test of IV1 $=2.069$, T-test of IV2 $=6.727$, and T-test of IV3 $=4.141$. The significance level of all independent variables is less than (0.05). Accordingly, the null hypotheses (H0, H0.1, H0.2) were rejected, and the alternative hypotheses (H1, H1.1, H1.2) were accepted.

\section{Discussion}

The relationship between variables is linear. The test of linearity relied on plotting the regression standardized residual against the expected value. The conceptual study framework did not break this assumption when no relationship existed between the expected and residual values.

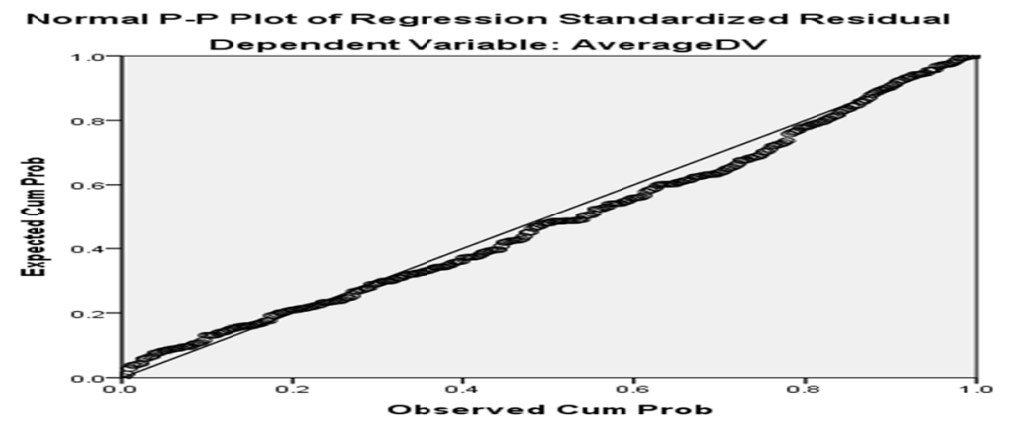

Figure 2. Standardized residual against the expected value - the main hypothesis

The objectives of the study were to gain a helpful knowledge about the impact of facilities on investment promotion. The researcher summarized the data analysis and results through the conclusions, which are related to the study's hypotheses after testing the data collected from the participants' responses through the distributed questionnaire.

The study found that most of the respondents have high education, academic qualification, and good experience, 
which show that human competencies and sufficient knowledge play a considerable role in creating an appropriate investment climate (Tembe \& Xu, 2012). Governmental reforms, policies, and strategies are relevant in achieving local economic development and growth, increasing productivity, and creating attractive business environment, which contribute greatly to increasing the flow of investments (Al-Fawwaz, 2016). Complementary services, facilities, supply, transportation, logistical services, communication systems, and strategic geographic locations help greatly in achieving the investment climate that attracts investment and stimulates the wheel of the economy. This result is in line with that of previous studies (Serhieieva, 2015; Stanković \& Radenković, 2017). The study found out that robust infrastructure, which is represented in many aspects, is important for the sustainable operations. Robust infrastructure involves the linking process of people, technology, and activities in addition to specialized maintenance teams and the required support for system problems. This variable is also crucial in developing the businesses to the next level and contributes to ensure the flow of services and creates the attractive environment for investments. This result is also reached by Gani and Mainul (2012) and United Nations Publication (2004, p. 41). As an extension to previous studies (Karyadi \& Puspita, 2016; Al-Shammari \& Al-Sarhan, 2012), the current research concluded that investment law benefits in addition to other financial incentives, such as competitive rental prices, tax exemptions, tax reduction, financial grants, custom exemptions, and investment incentives, have an effective impact on the promotion of local and FDIs.

\section{Conclusion}

The study reached several conclusions. The main one is the strong influence of robust infrastructure, complementary services, and investment law benefits on investment promotion. Countries without resources must improve their business climate to encourage investments. Many threats and challenges hinder investment promotion, such as contract issues, economic risks (inflation and interest rates), multiplicity of government authorities, and legislative complexities. Governments have the means to make conducting businesses and projects easier for people.

\section{Recommendations for Future Research}

The researcher makes recommendations that are useful for promoting local and FDIs in Jordan as well as future research efforts. Jordan needs to focus on developing integrated strategic plans that identify basic needs. These plans should be long term to allow the government to better coordinate development and improve its impact. In so doing, development that helps investment promotion can be achieved.

Increasing the financial and tax incentives, facilitating the laws and procedures of work and focusing on the facilities of banking and insurance sectors and flexibility of the laws and legislation are necessary steps. These courses of action contribute greatly to increasing local and foreign investment flows, and, in turn, help a country create an attractive environment for investments. Moreover, the National Investor should be given the same privileges, such as the foreign investor in King Hussein Business Park, to encourage national capital to contribute to investment. Using specialized research and development centers to evaluate the units listed in the investment promotion programs, ensures the implementation of these programs in King Hussein Business Park.

\section{References}

Al-Fawwaz, T. (2016). Foreign Direct Investment and Economic Growth in Jordan: Semi-Annual Data for the Period (2000-2013). Dirasat: Administrative Sciences, 43, 617-627.

Al-Shammari, N., \& Al-Sarhan, A. (2012). Foreign Direct Investment in Developing Asia According to the Location Advantage Hypothesis. Arab Journal of Administrative Sciences, 19(3), 429-448.

Arabyat, Y. (2016). The Impact of Foreign Direct Investment on Economic Growth in Jordanian: Analytical Study of the Period (1995-2012). Dirasat: Administrative Sciences, 43, 395-408.

Chowdhwry, M., \& Shao, Y. (2016). Foreign Direct Investment Determinants in Bangladesh Ready-Made Garments Industry. CLEAR International Journal of Research in Commerce \& Management, 7(3), 43-48.

Dorożyński, T., Świerkocki, J., \& Urbaniak, W. (2014). Attracting FDI to the Region of Lodz by its Local Government. Comparative Economic Research, 17(2), 101-118. https://doi.org/ 10.2478/cer-2014-0016

Frimpong, S., \& Nubuor, D. (2013). Research on Strategies to Attract and Retain Foreign Direct Investment (FDI) in Oil and Gas Industry in Ghana. School of Economics, Wuhan University of Technology.

Gani, M., \& Mainul, A. A. (2012). Infrastructure Problem and Investment Climate in Bangladesh. Economics, Management \& Financial Markets, 7(3), 70-82. 
Hair, J. F., Black, W. C., Babin, B. J., \& Anderson, R. E. (2010). Multivariate Data Analysis (7th ed.). rentice Upper Saddle River, N.J.: Prentice-Hall International.

Hair, J., Anderson, R., Tatham, R., \& Black, W. (1995). Multivariate Data Analysis with Reading (4th ed.). Upper Saddle River, N.J.: Prentice-Hall International.

Issani, A., \& Sallali, B. (2016). Evaluation of the FDI Climate in Algeria during the Period (2002-2012). University of Batna, Media Center - Algeria.

Karyadi, F., \& Puspita, L. (2016). Indonesia: Indonesia Updates Tax Facilities for Investment. International Tax Review, p. 9.

Kaur, M., Khatua, A., \& Yadav, S. (2016). Infrastructure Development and FDI Inflow to Developing Economies: Evidence from India. Thunderbird International Business Review, 58(6), 555-563. https://doi.org/10.1002/tie.21784

Koo, M. J. (2016). Is the Investment Tax Credit Really More Coercive Than the Personal Property Tax Exemptions in the Cuno Controversy? Tax Lawyer, 69(4), 817-848.

Magableh, S., \& Ajlouni, S. (2016). Determinants of Private Investment in Jordan: An ARDL Bounds Testing Approach. Dirasat: Administrative Sciences, 43(1), 263-274. https://doi.org/10.12816/0028461

Reich, F. (2006). Unfavorable Aspects of Czech Republic's Private Equity Environment: Limitations on Institutional Investors and Exit Problems. Journal of Pension Planning \& Compliance, 31(4), 9-30.

Rondinelli, D., \& Burpitt, W. (2000). Do Government Incentives Attract and Retain International Investment. Policy Sciences, 33(2), 181-205. https://doi.org/10.1023/A:1026555732212

Serhieieva, O. (2105). Investment Climate in Ukraine: Reality and Perspectives. Socio-Economic Problems \& the State, 13(2), 254-260.

Sharmen, A., Zahurul, A., \& Khaled, A. (2015). Laws, Regulations, Formalities and Facilities/Incentives on Investment: A Case of Bangladesh. USV Annals of Economics \& Public Administration, 15(2), 222-233.

Stanković, J., \& Radenković, D. (2017). The Role of Business Environment in the Promotion of Investment Activities: Case Study of Cities and Municipalities in the Republic of Serbia. University of Niš, Faculty of Economics, Niš, Serbia, TEME: Casopis za Društvene Nauke.

Tanaka, K., \& Arita, S. (2016). Does Policy Reform Promote FDI in Developing Economies? A Firm-Level Simulation Approach. Journal of Economic Policy Reform, 19(3), 281-304. https://doi.org/10.1080/17487870.2015.1100083

Tembe, P., \& Xu, K. (2012). Attracting Foreign Direct Investment in Developing Countries: Determinants and Policies: a Comparative Study between Mozambique and China. International Journal of Financial Research, 3(4), 69-81. https://doi.org/10.5430/ijfr.v3n4p69

United Nations Publication. (2004). Policies Aimed at Attracting Foreign Direct and Intraregional Investment in The ESCWA Region: Improving The Climate for Foreign Direct Investment and Mobilizing Domestic Savings, Case Studies of Bahrain, Jordan and Yemen. Economic and Social Commission for Western Asia, New York, United Nations, (OCoLC) 55489452 04-0076-February 2004-1300.

\section{Copyrights}

Copyright for this article is retained by the author, with first publication rights granted to the journal.

This is an open-access article distributed under the terms and conditions of the Creative Commons Attribution license (http://creativecommons.org/licenses/by/4.0/). 